\title{
EVALUATION OF THE SUSTAINABILITY OF THE VALLE DE BRAVO RESERVOIR, MEXICO, AS A WATER-SUPPLY SOURCE
}

\author{
ALFONSO G. BANDERAS ${ }^{1} \&$ REBECA GONZÁLEZ-VILLELA ${ }^{2}$ \\ ${ }^{1}$ Coordination of Profesional and Institutional Development, Mexican Institute of Water Technology, Mexico \\ ${ }^{2}$ Coordination of Treatment and Quality of Water, Mexican Institute of Water Technology, Mexico
}

\begin{abstract}
The reservoir of the Valle de Bravo (BVR) dam shows acute symptoms of progressive cultural eutrophication that distances it progressively from its function as a supply source. The reservoir and the city of the same name are tourist attractions, so that, as demotechnics progress, the environmental deterioration reduces the basin capacity to provide environmental services and sustain the economic and social development of its own inhabitants. The BVR provides drinking water to the Metropolitan Area of the Valley of Mexico (MAVM: 22 million inhabitants), through the Cutzamala System (CS), hence, since 2003 there is a Strategic Plan for the Environmental Recovery of the Basin of Amanalco-Valle de Bravo (SPERBAR), whose effectiveness is evaluated in this study, reviewing the concerning scientific and technical literature, with the objective to know what we can expect from the increases in population, pollution, sedimentation and the change of the reservoir use, respect to its sustainability as a supply source. The growing environmental impact exceeds the efforts to retain the resilience of the aquatic ecosystem. The participation of experts has not been sufficient to clarify the situation, control eutrophication and mitigate its impacts, since economic interests are imposed on the use of the reservoir, suggesting that the principles and objectives of sustainable development could not be transposed onto the specific context of tourism. The situation demands a different approach in water management and an inclusive legislation that meets the objectives of the sustainable development of all the interests at stake. Some works and actions are recommend.

Keywords: watershed, reservoir, eutrophication, management, policy, sustainability.
\end{abstract}

\section{INTRODUCTION}

The CS supplies drinking water with conventional treatment to the MAVM (22 million people), which receives many resources as contributes $23 \%$ of the Gross Domestic Product (GD; [1]). The Demotehnic [2] into the MAVM, amplifies the environmental problems in its reduced area, deteriorating long stretches of the rivers Pánuco, Lerma and Balsas borned at the Mexican central plateau. Together with aridification, desertification and aquifers over-exploitation, already limits water availability here and in broad zones of the centre, north, and northwest of the country [3], VBR included.

Known before 1979 as Miguel Aleman Hydroelectric System (MAHS), the CS came into operation in 1982 , contributing $14.7 \mathrm{~m}^{3} \mathrm{~s}^{-1}(24 \%)$ to the water supply system of the MAVM, currently composed of four sources: aquifers $(66 \%)$, Lerma System $(8 \%)$, superficial springs (2\%) and CS [4], [5]) (Note: CNA is called Conagua since 2000, but they are the same entity). The VBR and its watershed are part of the CS. It is $615.5 \mathrm{~km}^{2}$ and includes 61 springs and the smaller San Simon basin, which feeds three ones (Fig. 1).

The inhabitants and beneficiaries of the reservoir have expressed to the authority their concern about the recurrent appearance of eutrophication symptoms. Thus, the National Water Commission and the Mexican Institute of Water Technology (IMTA), since 2003 have guided the SPERBAR, in order to review and update the proposed projects (including those in the 2008 Environmental Program), update the original database and generate indicators on the impact of fragmentation and forest felling, erosion and proliferation of irregular 
garbage dumps, and polluting effluents from people and livestock [6], [7]. The Consensus Matrix of Priority Problems included in the SPERBAR, made with 63 representatives of the basin organizations, includes: water quantity and quality loss (37); forest degradation (15); inadequate/inapplicable legislation, social participation and environmental culture (8); soil degradation (5); social and economic lags (3); insufficient environmental monitoring (3); anarchic urban growth (1).

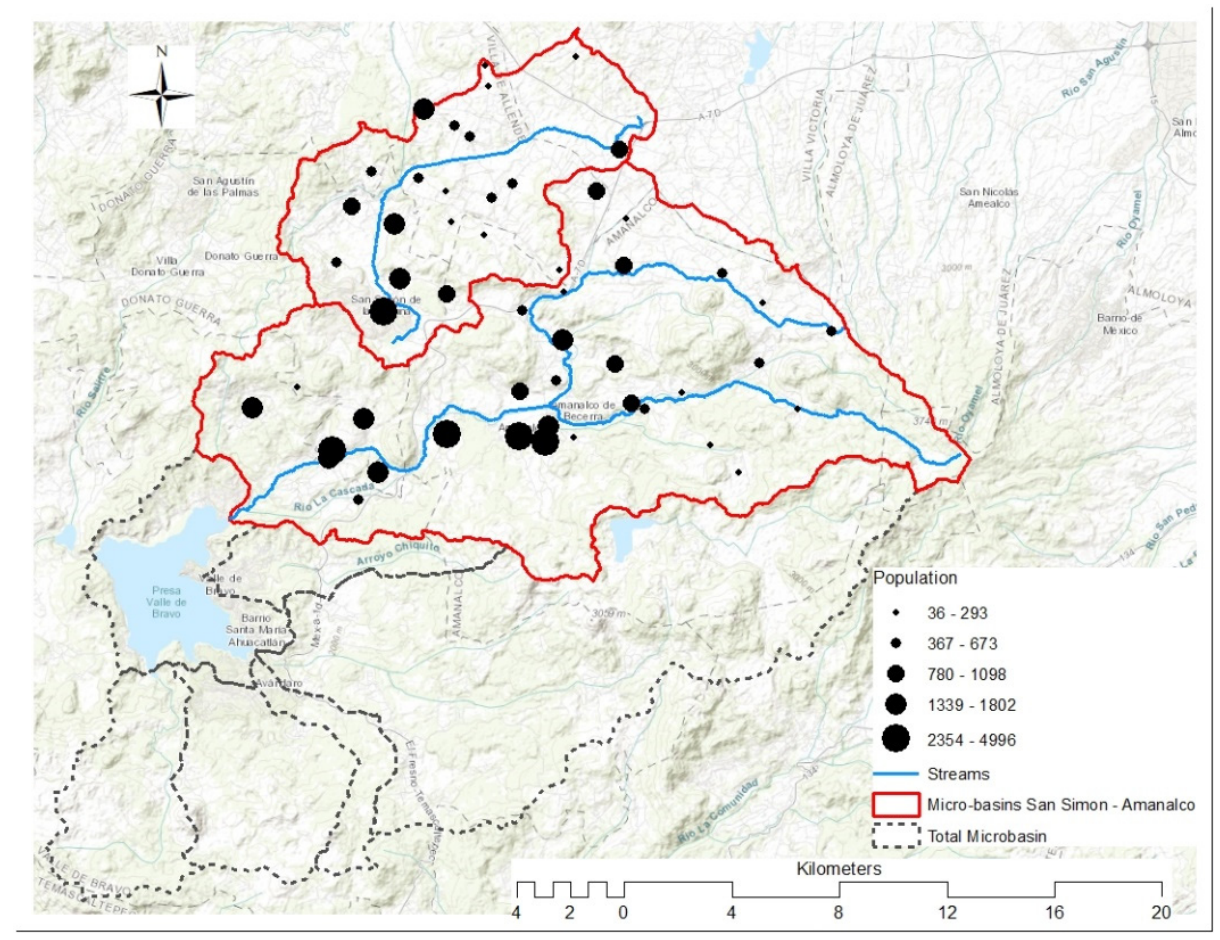

Figure 1: Valle de Bravo micro-basin location and its population density.

About water quantity and quality loss, the CNA and the IMTA studied the main contributor to the reservoir (Amanalco river), to 1) diagnose through the river's response to the effects of soil conservation jobs in the watershed, carried out since 1992 [6]-[8]; 2) know the reservoir limnology [9]; 3) control the discharges to the reservoir and the phytoplankton toxic potential (Phycotoxin was detected in 1998: discussed later in the paper); 4) conserve springs [6], [7]; and 5) evaluate the efficiency of the municipal wastewater plant (done by IMTA in 2013: discussed later in the paper). Including 1) identify, locate and prioritize the main factors of ecosystem disturbance; 2) evaluate the river-reservoir system relationships, and the environmental quality of water; 3 ) develop indicators of the basin water quality; and 4) suggest restoration and conservation measures of water quality and quantity.

Therefore, the general objective of this study is to evaluate the sustainability, in the context of Sharpley [10], of the VBR as a source of supply for the MAVM, fulfilling the following particular objectives: 1) update the knowledge on the reservoir condition; 2) assess the impact coming from its watershed; 3) prepare a diagnosis on its trophic evolution; and 4) suggest mitigation measures to maintain its current use. 


\section{STUDY AREA}

Valle de Bravo dam (VBD) is located in the Watershed IV: Río Balsas, with coordinates $19^{\circ}$ $21^{\prime} 30^{\prime \prime} \mathrm{N}$ and $100^{\circ} 11^{\prime} 00^{\prime \prime} \mathrm{W}$ (Fig. 1). It was completed in 1944 with $526 \mathrm{~km}^{2}$ of total catchment area; $148 \mathrm{~m}$ length, $56 \mathrm{~m}$ height and $457 \mathrm{hm}^{3}$ capacity at the Maximum Extraordinary Water Level (MEWL), at 1,833 m altitude. The reservoir had 1,700 ha, $21 \mathrm{~m}$ average depth, and $39 \mathrm{~m}$ maximum depth near the curtain [11]. It provided 10.8 of the 15.6 $\mathrm{m}^{3} \mathrm{~s}^{-1}$ required by the MAHS in the El Durazno Plant turbines [12]. Currently it sends $6 \mathrm{~m}^{3}$ $\mathrm{s}^{-1}$ to Los Berros drinking water plant. The municipal effluents must comply with certain mandatory sanitary. By 1997, a peripheral sewage collector and a $150 \mathrm{~L} \mathrm{~s}^{-1}$ treatment plant were added [13]-[15].

The sub-basin gives its name to the CS (Table 1). VBD is located at the confluence of several micro basins, being Amanalco River its principal affluent, which micro-basin is $35 \mathrm{~km}$ long, $7 \mathrm{~km}$ wide and $286 \mathrm{~km}^{2}$ area, extending from 3,250 to $1,820 \mathrm{~m}$ altitude, with $2,510 \mathrm{~m}$ average. The terrain is steep, especially between 2,375 and 3,250 $\mathrm{m}$ altitude. The watershed/reservoir areas ratio is $30: 1$.

Table 1: Characteristics and graduation of the Balsas River basin and smaller units [8].

\begin{tabular}{|l|l|c|c|c|}
\hline Unit & Name & $\begin{array}{c}\text { Area } \\
\left(\mathrm{km}^{2}\right)\end{array}$ & $\begin{array}{c}\text { Precipitation } \\
\left(\mathrm{km}^{3}\right)\end{array}$ & $\begin{array}{c}\text { Runoff } \\
\left(\mathrm{hm}^{3}\right)\end{array}$ \\
\hline Basin & Balsas River & 116,912 & 109,890 & 29,005 \\
\hline Sub-basin & Cutzamala River & 12,353 & 11.61 & 6,547 \\
\hline Micro-basin & Amanalco River & 233.6 & 0.222 & 126.14 \\
\hline Nano-basin & Garrapata Creek & 60.63 & 0.057 & 37.1 \\
\hline Nano-basin & El Faro Creek & 8.47 & 0.008 & 4.22 \\
\hline
\end{tabular}

\section{METHODOLOGY}

The information available in the Water Knowledge Center (CENCA: http//:cenca.imta.mx), of the IMTA was gathered including scientific papers, technical reports and thesis made in the study area, mostly unpublished but containing enough field data to address the issue. Following to Hodren et al. [16] the considered section of the Balsas river basin was graduated in subordinate units (Table 1). Then, the loss of quality and quantity of water is analyzed with a Systems Approach [17], [18]. The previous assessments are applied to weigh the interactions between the compartments identified in the watershed-reservoir ecosystem. Finally results are applied to improve the planning and integral resources management, with measures that protect them and make their use more efficient [8], [19], [20].

\section{RESULTS}

\subsection{Biophysical environment}

\subsubsection{Amanalco River}

Its watershed is located at west of the Mexico State, adjacent to Nevado de Toluca National Park. Includes the entire municipality of Amanalco, most of Valle de Bravo and smaller portions of Donato Guerra, Villa de Allende, Temascaltepec, Villa Victoria, Almoloya de Juárez and Zinacantepec (Fig.1).

Its Physiography shows hills with plateaus. The bedrock is 10 to $50 \mathrm{~cm}$ deep. Humic andosol of medium texture covers $74 \%$ of the area and Arctic acrisol in second term [21]. The river borns near the watershed edge, in the nano basins of two creeks: La Garrapata to 
the North, arising from a deforested area with grazing practices and seasonal agriculture on steep slopes; and El Faro to the South, arising from a forest subject to management and grazing. Both streams converge near the municipal head and in the vicinity of the wetland La Laguna, a useful trap of sediments and agrochemicals that was drained to be incorporated into agriculture.

Following the climatic classification of García [22], in the sub-basin are the Köppen climate types: (C (E) w2) above 3,200 m altitude (eastern part); (Cw2) from 2,200 to 3,000 $\mathrm{m}$ altitude; and ((A) Cw1) below 2,200 m altitude. Also, a climate type (A) C (W1) (W) is reported, slightly varying to (A) CW2 (W) (i') g in reservoir surroundings: semi-warm and sub-humid summer rains, 800 to $1,200 \mathrm{~mm}$ average annual precipitation, 5 to $10 \%$ of total rainfall in winter, with $2,000 \mathrm{~mm}$ evaporation and $18-22^{\circ} \mathrm{C}$ average temperature. The $\mathrm{P} / \mathrm{T}$ ratio is between 43.2 and 55.3. Dominant winds flow from north-northeast and northeast with maximum speed of $20 \mathrm{~km} \mathrm{~h}^{-1}$ from November to May, most frequently in March [5], [23].

In upper zones the main vegetation is pine-oak forest interspersed by secondary vegetation and seasonal agriculture that changes to irrigation in middle and lower zones [5], [21]. Also important are forestry, livestock and aquaculture, highlighting Amanalco Municipality as the main trout producer nationwide, with 65 farms producing 500 to 900 tons yearly, which generate $533 \mathrm{~T}$ of suspended matter; $91 \mathrm{~T}$ of ammonia; $3.75 \mathrm{~T}$ of nitrates; $4.8 \mathrm{~T}$ of phosphates; and $10.5 \mathrm{~T}$ of total phosphorus [12], [24].

The river crosses over 3,000 ha of irrigation and 7,500 ha of seasonal crops, where about $5,600 \mathrm{~T} \mathrm{yr}^{-1}$ of fertilizers are applied, partly assimilated by the crops, partly washed by runoff and infiltration, and partly removed by wind in the dry season. Around 1976, the river received domestic drains of 35,000 fixed and 15,000 floating people, plus diffuse contributions from livestock. Currently, this population has doubled. Table 2 shows the phosphorus $(\mathrm{P})$ and nitrogen $(\mathrm{N})$ loads in the reservoir tributaries around 1992. By 1993, the calculated erosion was $44.7 \mathrm{~T} \mathrm{ha}^{-1} \mathrm{yr}^{-1}$ (Table 3), mainly generated by seasonal agriculture. The reservoir capacity decreases $1.28 \mathrm{hm}^{3} \mathrm{yr}^{-1}$, average rate, due to alluvium [8].

Table 2: $\mathrm{P}$ and $\mathrm{N}$ loads from the influents to the $\mathrm{VB}$ reservoir [9].

\begin{tabular}{|l|c|c|c|c|c|}
\hline River & $\begin{array}{c}\text { Flow } \\
\left(\mathrm{hm}^{3} \mathrm{yr}^{-1}\right)\end{array}$ & $\begin{array}{c}\mathrm{P} \text { load } \\
\left(\mathrm{T} \mathrm{yr}^{-1}\right)\end{array}$ & $\%$ & $\begin{array}{c}\mathrm{N} \mathrm{load} \\
\left(\mathrm{T} \mathrm{yr}^{-1}\right)\end{array}$ & $\%$ \\
\hline Amanalco & 90 & 26.518 & 57 & 161.84 & 58 \\
\hline Molino & 58 & 0.81 & 2 & 29.968 & 10.8 \\
\hline Santa Mónica & 4.2 & 0.266 & 0.69 & 3.06 & 1 \\
\hline Gonzalez & 20.3 & 0.22 & 0.5 & 9.876 & 3.6 \\
\hline Carrizal & 12.1 & 0.121 & 0.3 & 9.379 & 3.4 \\
\hline Rainfall & 14.5 & & & & \\
\hline Total & & 27.935 & 60 & 214.143 & 77 \\
\hline
\end{tabular}

Table 3: Volume loss rate of VB reservoir from 1940 to 1993.

\begin{tabular}{|l|c|c|c|}
\hline Year & $\begin{array}{c}\text { Volume } \\
\left(\mathrm{hm}^{3}\right)\end{array}$ & $\begin{array}{c}\text { Difference } \\
(\text { years })\end{array}$ & $\begin{array}{c}\text { Loss rate } \\
\left(\mathrm{hm}^{3} \mathrm{yr}^{-1}\right)\end{array}$ \\
\hline 1944 & 410 & 0 & - \\
\hline 1973 & 405 & 29 & 0.16 \\
\hline 1993 & 364 & 20 & 2 \\
\hline
\end{tabular}


Two hundred and eigth physicochemical samples of forty variables were evaluated from 1984 to 1996 (river 156, reservoir 49, other 13). Largest Pearson correlations $(\mathrm{p}<0.05)$ emphasize natural relationships, i.e. hardness is determined by magnesium $(0.93)$; salinity by sodium (0.85); alkalinity by bicarbonate (0.84); carbonate increases as reservoir volume decreases (-0.88). And reveal human interference, i.e. detergents (MBAS), providing P, are linked to domestic drains (0.85), whose organic waste increases $\mathrm{CO}_{2}$ by microbial activity. Phosphorus grows as reservoir volume does $(0.80)$, due to leachates of dumps and fertilizers come into the runoff [8].

The springs presented higher content of nitrate derived from the subsoil, and lower of ammonium derived from fertilizers. At the micro-basin lower half, eleven extreme observations (EO), detected in several creeks measure intermittent human impact due to domestic effluents from the watershed and urban areas. One EO comes from a highly mineralized spring. Their averages exceed total average of each variables by 57 times for $\mathrm{NH} 4,51$ times for Mn, 26 for total N, 21 for MBAS, 8 for $\mathrm{P}$ and 4 for $\mathrm{CO}_{2}$.

The multivariate statistic defined an altitudinal gradient in the micro-basin. Natural leachates predominate in high and middle zones, but contaminants grows in lower parts as human settlements increase. So that, $\mathrm{P}$ and $\mathrm{NH}_{4}$ start to increase disproportionately from the upper-middle zone, especially between Amanalco de Becerra (middle zone) and San Bartolo (lower-middle zone), where La Laguna wetland was drained. $\mathrm{Ca}$ and $\mathrm{Mg}$ bicarbonates predominate in highlands water, where the lower temperature and $\mathrm{pH}$ dissolve Si. But downstream, increasing temperature and $\mathrm{pH}$ decreases dissolved $\mathrm{CO}_{2}$ and increase carbonate, which predominates in the lower parts and in the reservoir, favoured by a greater evaporation. $\mathrm{Mg}$ and $\mathrm{Ca}$ salts increase at the lower parts due to soil leachate, agricultural lime, streams confluence and evaporation.

\subsubsection{Municipal treatment plant}

The municipal treatment plant (MTP) efficiency was evaluated by the IMTA in 2013 (Proyect TC-1339.3 unpublished) to prevent incidents to pouring treated water into a supply source, focussing on emerging and unregulated compounds that can affect the man and wildlife health [25]. Eight hundred molecules were detected, near 75 resisted the treatment, few of which exceeded the limits allowed, and rains and the reservoir dilute their effect. It was assumed there is no health risk in the short term if raw or treated wastewater of the plant is accidentally consumed. It was suggested to improve the plant efficiency regard pesticides and solvents dangerous to aquatic environment.

\subsubsection{Valle de Bravo reservoir}

The original volume was $437 \mathrm{hm}^{3}$ with $17.3 \mathrm{~km}^{2}$ area at the Maximum Ordinary Water Level (MOWL), with $7.3 \mathrm{~km}$ maximum length, $6.3 \mathrm{~km}$ max. width, and $35 \mathrm{~m}$ max. depth. In 1991, it was $335 \mathrm{hm}^{3}$ and the outputs were: extraction 153.8, evaporation 27.8 and filtration $21.6 \mathrm{hm}^{3}$. During 2002-2005, the volume was $347.9 \mathrm{hm}^{3}, 89 \%$ of its maximum capacity [26]. Around 2015, sedimentation reduced $21 \%$ of the reservoir max. capacity, keeping $361 \mathrm{hm}^{3}$. The previous minimum volume was recorded in mid-July 1990 with $210 \mathrm{hm}^{3}$. A max. level of $428 \mathrm{hm}^{3}$ (without discounting the azolve, we assume), was achieved in 2008 stopping extractions and transferring water, since December 2006, from the Colorines dam, covered with water lily [9], [14] and 2015 [24], [27].

Aquatic vegetation: around 1987, the water lily density was $67 \mathrm{~kg} \mathrm{~m}^{-2}$ and biomass $121,800 \mathrm{~T}$, with an average of 50,000 $\mathrm{T}$ in the dry season (March), and a minimum during rains, but with greater coverage. The lily contained $94.9 \%$ humidity, $0.086 \%$ phosphorus, and $1.48 \%$ nitrogen in average [9]. A Hydrilla sp similar plant, develops well on euphotic 
zone soil. Microcystin-LR was detected in June 1999, with values of 2,551 $\mathrm{mg} \mathrm{kg}^{-1}$ (dry basis weight). In July 2001, it was 3,761 $\mu \mathrm{g} \mathrm{g}^{-1}$ [28]. In July 1998, a bloom of Anabaena spiroides did cover 60 to $70 \%$ of the reservoir area, and the detected anatoxin- $a$ indicates the presence of its toxigenic strains.

Between July 2000-July 2001, euphotic zone reached $4.3 \mathrm{~m} ; 40 \%$ of 68 phytoplanktonic taxa were dominant, notably Chlorococcales and cyanobacteria. Snowella septentrionalis highest density was observed in April, and Microcystis botrys, M. flos-aquae, $M$. wesenbergii and Mougeotia sp. in October, at the beginning and end of stratification, respectively. These pulses coincided with the periods of $\mathrm{N}$ limitation. Dominance of these species and a highly fluctuating Shannon-Wiener diversity index ( 0.45 to 2.35 bits), point to disturbed and eutrophic conditions [29]. In 2008, an increase of planktonic diatoms biomass and a significant decrease of harmful algae, as Nostocales, were observed, both related to a water quality improvement [27]. We note the last study coincides with the maximum water level reached by pumping.

Aquatic fauna: Between September 1969-September 1970, twenty genera and six species of Hemiptera (9), Coleoptera (6), Ephemeroptera (5), Odonata (4), Plecoptera (1) and Trichoptera (1) were identified, the latter in places near the streams mouth. Also abundant were the paclifer Cambarellus montezumae, largemouth bass Micropterus salmoides and bluegill moray Lepomis macrochirus [30]. Ichthyofauna populations, as rainbow trout, charal, white fish, common carp, israeli carp and gilthead carp, and green mojarra, African mojarra and bluegill mojarra, introduced around 1980, have declined due to toxic conditions by mixing [9].

In 2006, the average density of zooplankton $\left(847\right.$ ind $\left.\mathrm{L}^{-1}\right)$ doubled its total abundance compared to November 2004-October 2005 period. The rotifers Anuraeopsis, Keratella, Polyarthra and Trichocerca ( $80 \%$ of total numerical abundance) dominated as in temperate lakes. The abundance of dominant rotifers depended on the availability of food and $70 \%$ of its variation was explained by temperature, dissolved hypolimnetic oxygen and $\mathrm{pH}$ [31]-[33].

Limnology: the reservoir temperature is $17.5-23.5^{\circ} \mathrm{C}$ It stratifies in summer with an average stratification period of $241.4 \pm 30.1$ days The epilimnion is 7 to $8 \mathrm{~m}$ thick. Dominant wind blowing strongly in dry season (December to May), promotes the mixing (monomictic) of the whole water body (holomixis) suffocating and intoxicating the aquatic biota and fertilizing the water with $\mathrm{N}$ and $\mathrm{P}$ compounds, favouring the massive growth of blue-green algae (cyanophytes) throughout the water body. The rest of the year, the moderate wind apparently causes an upwelling of nutrients to the limnetic zone, favouring phytoplankton grow near the dam curtain [26], [29], [34], [35].

In 1992 oxycline did not show anoxia, at 2001 it was totally anoxic [26]; transparency oscillated between $1.5 \mathrm{~m}$ in the littoral, up to $2.5 \mathrm{~m}$ in the limnetic zone; euphotic zone was 3.4 to $5.2 \mathrm{~m}$ thick; Chlorophyll $a$ had a maximum of $52.8 \mathrm{mg} \mathrm{m}^{-3}$ in February in front of Carrizal River mouth, a minimum of $10.5 \mathrm{mg} \mathrm{m}^{-3}$ in July near the curtain; with $29.2 \mathrm{mg} \mathrm{m}^{-3}$ annual average. The reservoir was eutrophic with the $\mathrm{P}$ trapped in sediments as the main limiting factor of productivity [9]. We think this conclusion opposed to the high COD rates associated with the high nitrification rates observed.

The reservoir primary productivity from 1998 to 1999, was performed by genera as Anabaena, Microcystis, Nostoc and Oscillatoria, and the N/P ratio of 0.98 to 5.68 pointed to a $\mathrm{N}$ limitation. In April, a ratio of 28.32 indicated P limitation [31], the rest of the year the presence of $\mathrm{N}$-fixing algae, such as Anabaena, Microcystis and diatoms, indicate sufficiency of P. Diatoms dominated in cold and dry months. In 2001 to 2002, chlorophyll averaged $21 \mu \mathrm{g} \mathrm{L}{ }^{-1}$ with frequent blooms up to $88 \mu \mathrm{g} \mathrm{L}^{-1}$ limited by $\mathrm{N}$ during stratification 
[36]. This alternating control of primary productivity is recurrent in lakes of Mexican highlands, and points to a summer maximum primary productivity P-limited [37].

\subsubsection{Reservoir management}

The change from MAHS (before 1982) to CS (now) implied a change in the reservoir Hydraulic Retention Time (T), that is, the lapse to empty the reservoir by outflow [19]. Considering the original volume at the MOWL, outflows changed from 10.8 to $6.5 \mathrm{~m}^{3} \mathrm{~s}^{-1}$, and T from 1.32 to 2.13 years (62\% larger), i.e. 9.72 months more to renew the water. Around 1990, $\mathbf{T}$ was 2.18 years [9], that is, 10.3 more months. Besides this, surface water is (or was) extracted when the reservoir stratified [35], involving 109 to $140 \mathrm{hm}^{3}$ year ${ }^{-1}$, or 78 to $91 \%$ of the total extractions $\left(153 \mathrm{hm}^{3}\right.$ year-1), and between 30 and $39 \%$ of the reservoir volume $\left(361 \mathrm{hm}^{3}\right)$. We think, this action exposes the hypolimnion. No data could be found on the quality of the water transferred from the Colorines dam to the VBD.

\subsection{Social environment}

\subsubsection{Demography}

From 1970 to 2010 the population of VB municipality almost doubled (190\%), and may reach 100,000 inhabitants in 2020 (Table 4). This growth of 350\% in the micro-basin can exceed $2,000 \%$ if tourism is included. From 1990 to 2000 agricultural and urban land grew by $200 \%$ and $167 \%$, proportionally increasing pollutants and sediments loads to urban and agricultural sewages. This growth has not stopped [38]-[40].

Table 4: Evolution of population and land use in the VB Municipality.

\begin{tabular}{|l|c|c|c|c|c|c|c|c|}
\hline Año & $\begin{array}{c}\text { Agríc. } \\
\text { (ha) }\end{array}$ & $\begin{array}{c}\text { Incr. } \\
\%\end{array}$ & $\begin{array}{c}\text { Urban } \\
\text { (ha) }\end{array}$ & $\begin{array}{c}\text { Incr. } \\
\%\end{array}$ & Popul & $\begin{array}{c}\text { Incr } \\
\%\end{array}$ & $\begin{array}{c}\text { GDP } \\
3^{\text {rd }}\end{array}$ & $\begin{array}{c}\text { Incr. } \\
\%\end{array}$ \\
\hline 1970 & & & & & 35,000 & 0 & & \\
\hline 1990 & 4,930 & 0 & 1,350 & 0 & 36,135 & 3 & & \\
\hline 2000 & 9,865 & 200 & 2,250 & 167 & & & & \\
\hline 2010 & & & & & 66,599 & 190 & 7,000 & 0 \\
\hline 2015 & & & & & & & 12,000 & 41 \\
\hline 2020 & & & & & 100,000 & 286 & & \\
\hline
\end{tabular}

PROCUENCA [41], an escrow of VB micro-basin sponsored by 14 companies as Conagua, BANCOMER and the State of Mexico government, says "most of the 120,000 watershed permanent inhabitants live in poor communities pressing natural resources through activities of primary sector as agriculture". But the municipal govern [21] says "tertiary sector occupies $68 \%$ of the workforce, tourism included, and enters more money into the Municipality and State coffers through the touristic amenities". These amenities are settled on the reservoir banks, where the floating population generate garbage and waste, especially on holidays. The escrow found twelve (35\%) highly contaminated and $5(15 \%)$ contaminated (fecal coliforms) in 34 samples taken by themself in August 2016 in Amanalco river, revealing unhealthy conditions due to the outdoor fecalism (including livestock), and domestic sewage from settled communities along the main road which runs parallel the river. Thus, the efforts made in the aforementioned SPERBAR apparently have not had an effect, since from 1992 to 2005 the N and P discharges have grownby $276 \%$ for P and $203 \%$ for $\mathrm{N}$ [26], almost the same as population did (Table 4), and the reservoir deteriorates more and more. 


\subsubsection{Watershed management policies}

The Valle de Bravo Trust (\$74.6 million MN) was temporarily created in 2005 [42], with contributions of the National Commission of Natural Protected Areas of Environment Ministry (SEMARNAT-CONANP: \$31.9 million), the state government (\$20.6 million) and Televisa Foundation (\$21.4 million), to acquire properties in the margins of the "Valle de Bravo Water Sanctuary" protected wetland area [43], via law, public interest, and Bank interest (about $\$ 726$ thousand NM). The Sanctuary approaches the reservoir in steep areas and does not include urbanized, current or planned shores. The properties would be donated to the Federation because "the temperate environment is threatened by soil erosion and degradation, forest fires, urban development, extensive cattle ranching, illegal logging and expansion of the agricultural border".

The Trust has expropriated for conservation purpouses, about 79 ha of the San Juan Atezcapan ejido, paying compensation of $\$ 20$ per $^{2}$ [44], [45]. However, the case shows that the land adjacent to the reservoir is marketed by real estate agents that quote between 300 and 400 USD $^{2}$ [46], stimulating within the basin the properties supply offered for "real estate developments" (e.g. El Financiero [47] and Trovit [48]).

\section{DISCUSSION}

The biological and physicochemical data from studies carried out by official, academic and private entities showed recurrently the increasing pollution in the contributors and in the VB reservoir, culturally eutrophicated in a short time: In the 80 s it was qualified as oligotrophic, but in 2003 and 2004, it had bad appearance and biological, physical and chemical parameters typical of eutrophic conditions [24].

Althought the Microcystis aeruginosa populations did not exceed 5\% of the total phytoplankton abundance when analized, its proliferation can explain the closure of the reservoir to navigation from 2011 to 2012 (below) [49]. So, it was recommended in 1998 (Project TC-9815 IMTA unpublished) to control it, if necessary, with calcium hydroxide, but we think this method would increase water costs, as well as dissolved $\mathrm{Ca}$, hardness and alkalinity in the reservoir.

Vollenweider equation [19] shows that dissolved solids concentration depends on $\mathbf{T} / \mathbf{z}^{\prime}$ ratio. The only factor can reduce solids concentration is $z^{\prime}$ (mean depth), but less volume reduces depth, and concentration increass, especially due to silting, and/or to a very dry season, and/or if agriculture decreases inflows, or a combination of these three factors, as occurs in BVR. Since $\mathbf{T}$ has almost doubled, part of the waste from the previous season remains in the reservoir, adding self year after year to the waste coming from the micro-basin, accumulating self inexorably in the water and sediments.

When the reservoir belonged to the MASH, the extraction was higher and the volume lesser, favouring the solutes and pollutants washout. Pollutants were also less due to a smaller population, lesser the agricultural area and larger the tributaries contribution, however, this led to the bowl invasion with constructions below the MOWL. The washout could be effective again when sediments reduce the volume to an adequate level, but the micro-basin receives from 2.5 to 3 million people annually [21], [39], in hotels and own houses, surpassing 25 times the fixed population. Although their greater influx is temporary, the garbage and waste produced in holidays remains in the ecosystem lands and water, and in the treatment plant at best. The problem is usually attributed to the upper micro-basin population while tourism is promoted downstream, bypassing the quantity, not quality, of sewage drains, as evidenced by the following notes from a local newspaper and the CNA.

Teorema Ambiental (2012). (Environmental Theorem). Valle de Bravo, Mexico. June 29, 2012 [50]: "The Ministry of Communications and Transportation, at the request of the 
Conagua, kept the place closed to the navigation ... due to a persistent bad smell and bad taste of the water ... attributed to the algae Anabaena ... it is necessary to develop and promote sustainable tourism in the region, because the boatmen ... were more affected ... The Citizen Observatory ensures that ... Conagua and the municipality of Valle de Bravo, must immediately carry out a comprehensive management and sanitation program".

CNA: Press Release 139-12, Friday, July 6, 2012: "Cutzamala System water is suitable for human consumption because meets... Mexican standard. On Friday 6, Saturday 7, and Sunday 8, from 10 am to $5 \mathrm{pm}$, the navigation of the vessels ... in the eastern area of Valle de Bravo dam in the State of Mexico will be allowed, informed ... (Conagua), ... Given the weather conditions and the ... decrease of geosmin, ... the General Directorate of Merchant Marine, the Communications and Transportation Ministry, and the State of Mexico, allow the navigation of motor boats, yacht type".

In the present context, the only sustainable tourist is one who does not eat nor drink and, therefore, does not require agricultural land, nor drainages nor trash dumps. This problem has not been prioritized, as evidenced by the result of the survey carried out for the SPERBAR: only one of the 63 representatives pointed to the anarchic urban growth, but no one complained about the tourist increase.

We can see the weak side of the reservoir sustainability as supply source in Table 4, looking at the tourism income. The VB tertiary sector contributes $93.7 \%$ of GDP, and represents 33\% of the State of México GDP, reaching 12,000 million pesos in 2015, 41\% higher than sector GDP during 2010 [39]. This growth of $8.2 \%$ yearly exceeds the $7 \%$ proposed in the UN Objective 8.1 for Sustainable Development for developing countries, confirming the incompatibility between objectives 8,7 and 15 and, in this particular case, 11 (e.g. Hickel [51]).

This money has causes and consequences, i.e. the cost of clean and move the water of the $\mathrm{CS}$ is $\$ 6.145 \mathrm{~m}^{3}$ pesos [52], without include the costs of unsuccessful studies, actions and works from both public and private sectors to prevent the environmental degradation, as we have seen so far. Similar situations happen in other national water bodies, that could be exacerbated by the official boost to tourism without sustainable planning, if it exists.

The parallel increase of the population and the consequent and irreversible water contamination could not be stopped despite the efforts of: 1) the authorities responsible for planning and manage natural resources, 2) the non-governmental organizations interested in environmental conservation (for purposes whether altruistic or metallic), 3) the citizens, and 4) the interaction between the three. The basin participants (8), in the SPERBAR who think that the main problem is that the legislation, the social participation and the environmental culture are inadequate and/or inapplicable, are right. Although the properties offered into the micro-basin are not on the reservoir shore they are into the micro-basin fluvial corridors, so the perspective is worrisome, unless the Valle de Bravo Trust purchases the lands offered and uses them for conservation.

\section{CONCLUSIONS}

The main problem in the basin and the reservoir is the conflict that exists in the very definition of sustainable development: economic growth and sustainability [51], reflected in the scheduled use and the actual use of the reservoir.

Five (maybe six) steps were done, consciously or not, favoured eutrophication: 1) build the dam in a micro-basin where prevailing nutrient-rich volcanic soils; 2) change dam use, from hydro-electric generation to supply, increasing $\mathbf{T}$ and the load of suspended and dissolved substances; 3 ) extract epilimnetic water, thinning the epilimnion and exposing dirty hypolimnetic water, reinforcing the eutrophication; 4) pour to the reservoir the treatment 
plant effluent to maintain its level. This last water with high $\mathrm{N}$ and $\mathrm{P}$ load; 5) stimulate tourism into the micro-basin. The effect of importing water from the Tilostoc dam is in doubt. So, biodiversity has declined in favour of a few species eutrophication resistant, despite previous recommendation of discharge the treated wastewater outside the reservoir [8].

It is needed to know if the zooplankton food is produced into the reservoir (autotrophic) or comes from external sources (heterotrophy). This last case would implies extra income of organic matter from the micro-basin, which the waterbody could not depurate, aggravating the problem of hypolimnetic anoxia during winter mixing (e.g. Jasser et al. [53]).

As expected, the flocculant applied in the drinking water plant has grown in same proportion as $\mathrm{N}$ and $\mathrm{P}$ loads in the river discharges. Therefore, the recommendation that gave rise to the limnological studies in the reservoir no longer valid: reduce the flocculant applied in the plant [34], with the discomfort of the original inhabitants due to the discharge of the plant residuals in the surrounding lands.

It is necessary to improve the weighting of the problems generated in the site and the planning of the works and actions, as well as the prioritization, without simulation, of the economic benefits in favour of groups that have been marginalized for a long time [54]. Null result in conservation works and actions devalue social participation in water management and show that image and funds of institutions can be misused.

Must be emphasized that priority should be focused on redistributing the local population towards alternative income sources outside the micro-basin, and to control the agricultural frontier and its corresponding increases in drainages and sediments.

If the demotechnics does not stop, the work and actions to conserve the quality and quantity of the water in the VB micro-basin will be increasingly expensive and unsuccessful, and it is neither ecologically nor socially fair to invest so much money and labor in a conservation task that is doomed to fail to maintain the high water supply of a hydraulically almost unsustainable megalopolis due, in part, to the problem of the VBR discussed here, as well as to the desiccation of the sources of the Lerma River (with its social and economic consequences), and the sinking of Mexico City due to the overexploitation of the aquifer [55].

Other tourist sites in the country, such as Acapulco, Gro., Patzcuaro, Mich. (Project HC9825, 1998 unpublished [56]; and Cancún, Q. Roo (IMTA, 1998 unpublished), show similar results, sugesting that the principles and objectives of sustainable development cannot be transposed onto the specific context of tourism [10], adding to the worldwide environmental deterioration [57], characteristic of Anthropocene [58]. This requires check the preponderant economic development model [59], to achieve real sustainability in the face of the compromised situation between economic growth and the ecology [51], and apply a different approach to water management that includes the social aspects concurrently to the biological, ecological and hydrological aspects (e.g. Harper et al. [18]).

If this happens in such conspicuous systems as VB, under the gaze of national and international community, what can be expected from inconspicuous systems, such as subsurface waters under the effects of "fracking" [60]? This document is an example of what could be called "forensic sustainability", a necessary approach in the region to assess the state of natural resources and plan their conservation or recovery.

\section{RECOMMENDATIONS}

The floating population should be controlled by limiting land speculation and the development of tourism infrastructure, especially on the banks and within the reservoir, rivers and streams and on the surrounding hillsides and hills within the basin, at least to reduce to $3 \%$ GDP [51]. This would be more feasible also reducing, or at least controlling, the irrigated land. The correct function of the municipal treatment plant (MTP) and the peripheral 
wastewater collector should expand their capacity to serve the floating population during holidays. In addition, their water should not be poured into the waterbody but outside the dam, at least during the holiday season.

The water extraction from the epilimnion should be avoided and doing a intake scheduled management so that the hydraulic retention time can be shortened, at least in the rainy season.

The reservoir sediments must be removed by means of a low-impact dredging or through the deepest window of the intake. Given that there is no heavy industry in the region, sediment can be apply to fertilize the soils in the upper part of the basin affected for bad agricultural practices.

The sediments and agricultural pollutants must be retained in situ restoring both the wetland called La Laguna and the riparian vegetation of the river and its tributaries, and build manmade wetlands (e.g. Shutes [61]).

Determine the environmental flows of the tributaries to plan the allocation of volumes of water to progressively restore the ecosystem (e.g. Tharme [62]). Floating restaurants are a great attraction, but it is imperative that they be equipped with dry latrines and the excretions be stored in tanks and then handled in an environmentally safe manner.

\section{ACKNOWLEDGEMENT}

The authors thank Dr. Marcos Mijangos Carro for the preparation of Fig. 1.

\section{REFERENCES}

[1] Organization for Economic Cooperation and Development Publishing, OECD territorial reviews: Valle de México, México, 2015.

[2] Vallentyne, J.R., Freshwater supplies and pollution: Effects of the demophoric explosion on water and man. The Environmental Future, ed. N. Polunin, Macmillan Press: London, pp. 181-211, 1972. Cited in Limnolgy. Lake and River Ecosystems, R.G. Wetzel, 3rd ed., Academic Press: San Diego, 2001.

[3] Conagua, Estadísticas del Agua en México. Secretaría de Medio Ambiente y Recursos Naturales. Comisión Nacional del Agua, Mexico, 2015.

https://agua.org.mx/biblioteca/estadisticas-del-agua-en-mexico-edicion-2015/. Accessed on: 4 Apr. 2019.

[4] CNA, Sistema Cutzamala, Agua para millones de mexicanos, Gerencia Regional de Aguas del Valle de México y Sistema Cutzamala, Comisión Nacional del Agua, México: 2005. www.conagua.gob.mx/conagua07/publicaciones/publicaciones/ sistema-cutzamala.pdf. Accessed on: 5 Apr. 2019.

[5] Conagua, Diagnóstico para el manejo integral de las subcuencas Tuxpan, El Bosque, Ixtapan del Ordo, Valle de Bravo, Colorines-Chilesdo y Villa Victoria pertenecientes al Sistema Cutzamala, México, Banco Mundial, 2015, maps. http://documentos.bancomundial.org/curated/es/309801468189248037/pdf/99219P150092-SPANISH-WP-PUBLIC-Box393194B.pdf.

[6] IMTA, Planes estratégicos para la recuperación ambiental de la Cuenca AmanalcoValle de Bravo, Barrancas de Cuernavaca y Zona Conurbada de Morelos, y Laguna de Zumpango. Instituto Mexicano de Tecnología del Agua. Repositorio Institucional, México, 2012. http://repositorio.imta.mx/handle/20.500.12013/1538. Accessed on: 6 Jun. 2018.

[7] IMTA, Plan estratégico para la recuperación ambiental de la Cuenca Amanalco-Valle de Bravo, Actualización, Instituto Mexicano de Tecnología del Agua, Fundación Gonzalo Rio Arronte, México, 2012. https://agua.org.mx/wp-content/uploads/ 2014/05/Plan_cuenca_Amanalco_Valle_de_Bravo.pdf. Accessed on: 6 Jun. 2018. 
[8] Banderas, A., Caracterización de la cuenca hidrológica: Estudio de caso. Limnología de Presas Mexicanas. Aspectos Teóricos y Prácticos, eds J.L. Arredondo-Figueroa, G. Díaz-Zavaleta \& J. Ponce-Palafox, UAM-AGT: México, pp. 238-272, 2007.

[9] Olvera, V.V., Estudio de eutrofización de la presa Valle de Bravo. Ingeniería Hidráulica en México, 7(2-3), pp. 148-161, 1992.

[10] Sharpley, R., Tourism and sustainable development: Exploring the theoretical divide. Journal of Sustainable Tourism, 8, pp. 1-19. 2000.

[11] CFE, Balsas Medio. Boletín Hidrométrico 19, pp. 74-106. Comisión Federal de Electricidad, 1979.

[12] Sierra, L.N, Romero, A.T. \& Zizumbo, L., Desarrollo regional, electrificación y reorganización socioespacial en Valle de Bravo, México, 2012.

www.pueblosyfronteras.unam.mx/index.php/index.php/pyf/issue/view/15. Accessed on: 1 Jun. 2019.

[13] CNA, Contará Valle de Bravo con su planta de tratamiento. Vertientes 15:19, Comisión Nacional del Agua, México, 1997.

[14] CNA, Estadísticas del Agua en México. Cap. 4: Infraestructura hidráulica. Inventario nacional de plantas municipales de potabilización y de tratamiento de aguas residuales en operación. Secretaría de Medio Ambiente y Recursos Naturales, Comisión Nacional del Agua, México, 2011. www.conagua.gob.mx/CONAGUA07/Contenido/ Documentos/SINA/Capitulo_4.pdf. Accessed on: 4 Apr. 2019.

[15] Guido, J., Planta de tratamiento de aguas residuales de Valle de Bravo del Estado de México. Ingeniería Civil, 382, pp. 28-33. 2001.

[16] Hodren, C., Jones, W. \& Taggart, J., Managing lakes and reservoirs. North American Lake Management Society and Terrene Institute in cooperation with Office of Water Assessment, Watershed prot. Division, US Environmental Protection Agency, Madison, WI, 2001.

[17] DeBarry, P.A., Watersheds: Processes, Assessment, and Management, Wiley: New Jersey, 2004.

[18] Harper, D., Zalewski, M. \& Pacini, N. (eds), Ecohydrology: Processes, Models and Case Studies: An Approach to the Sustainable Management of Water Resources, Ill. Pacini, Nic., 2008.

[19] Ryding, S.O. \& Rast, W. (ed.), The Control of Eutrophication of Lakes and Reservoirs. UNESCO-The Partenosn Publishing Group, Man and Biosphere Series V. 1, Paris, 1989.

[20] González-Villela, R. \& Banderas, A. (Comp.), Aproximación Holística en el Manejo Integrado de las Cuencas, para la Conservación y Recuperación de los Cuerpos de Agua Superficiales: Caso de Estudio, Instituto Mexicano de Tecnología del Agua, 2016. www.imta.gob.mx/biblioteca/libros_html/aproximacion-holistica/\#30.

[21] AVB, Plan de desarrollo Municipal de Valle de Bravo 2016-2018. Ayuntamiento de Valle de Bravo Estado de México, 2016. www.valledebravo.gob.mx/wp-content/ uploads/2016/04/PDMVB-2016-2018-PUBLICADO-FINALa.pdf. Accessed on: 10 Jan. 2019.

[22] García, E., Modificaciones al Sistema de Clasificación Climática de Köppen, Serie Libros No. 6, Instituto de Geografía: Universidad Nacional Autónoma de México, 1964, Quinta Ed., 2004.

[23] MeteoBlue, Clima Valle de Bravo. www.meteoblue.com/es/tiempo/pronostico/ modelclimate/valle-de-bravo_m\%C3\%A9xico_3980621. Accessed on: 31 Jan. 2018. 
[24] Mota, K.E., Estudio de la Calidad del Agua del Vaso de la Presa de Valle de Bravo, Tesis Licenciatura, Facultad de Ingeniería, Universidad nacional Autónoma de México. Cap. 3: Revisión de la bibliografía, pp. 36-83. 2011. www.ptolomeo.unam.mx:8080/xmlui/bitstream/handle/132.248.52.100/479/A6\%20 CAPITULO\%203.pdf? sequence=6. Accessed on: 2 May 2018.

[25] Sumpter, J., Environmental effects of human pharmaceuticals. Therapeutic Innovation and Regulatory Science, 41(2), pp. 143-147, 2007.

[26] Ramírez-Zierold, J.A. et al., Changing water, phosphorus and nitrogen budgets for Valle de Bravo reservoir, water supply for Mexico City Metropolitan Area. Lake and Reservoir Management, 26, pp. 23-34. 2010.

[27] Valeriano-Riveros, M.E., Vilaclara, G., Castillo, F.S. \& Merino, M., Phytoplankton composition changes during water level fluctuations in a high-altitude, tropical reservoir. Inland Waters, 4(3), pp. 337-348, 2014.

[28] Ramírez-García, P., Martínez-Romero, E., Martínez-Salgado, M.D. \& EslavaCampos, C.A., Cianobacterias, Microorganismos del Fitoplancton y su Relación con la Salud Humana, Instituto Nacional de Ecología: México, pp. 1-18, 2004.

[29] Gaytan-Herrera, M.L., Martinez-Almeida, V., Oliva-Martinez, M.G., Duran-Diaz, A. \& Ramirez-Garcia, P., Temporal variation of phytoplankton from the tropical reservoir Valle de Bravo, Mexico. Journal of Environmental Biology, 32, pp. 117-126, 2011.

[30] Bueno-Soria, J. \& Márquez, C., Algunos insectos acuáticos de la Presa de Valle de Bravo. Revista de la Sociedad Mexicana de Historia Natural, 36, pp. 351-364, 1975.

[31] Ramírez-García, P., Nandini, S., Sarma, S.S.S., Robles-Valderrama, E., Cuesta, I. \& Dolores-Hurtado, M., Seasonal variations of zooplankton abundance in the freshwater reservoir Valle de Bravo (Mexico). Hydrobiologia, 467, pp. 99-108, 2002.

[32] Jiménez C.J., Sarma, S.S.S., Merino-Ibarra, M. \& Nandini, S., Seasonal changes in the rotifer (Rotifera) diversity from a tropical high altitude reservoir (Valle de Bravo, México). Journal of Environmental Biology, 30(2), pp. 191-195, 2009.

[33] Sarma, S.S.S., Gulati, R.D. \& Nandini, S., Proceedings of the Plankton Ecology Group (PEG) workshop in Mexico City (12-18 February 2012). Inland Waters, 4, pp. 255256, 2014.

[34] Olvera, V., Bravo-Inclán L. \& Sánchez-Chávez, J., Aquatic ecology and management assessment in Valle de Bravo reservoir and its watershed. Aquatic Ecosystem Health and Management, 1, pp. 277-290, 1998.

[35] Alonso, H.F., Dinámica de la Estratificación Térmica en el Embalse de la Presa Valle de Bravo, Medición y Simulación Numérica, Tesis de Maestría, Centro de Investigación Científica y de Educación Superior de Ensenada, Baja California, México, 2016. file://C:/Users/atbandera/AppData/Local/Packages/Microsoft. MicrosoftEdge_8wekyb3d8bbwe/TempState/Downloads/tesis_Alonso_Peinado_Hu mberto_Francisco_12_oct_2016\%20(1).pdf. Accessed on: 12 Mar. 2018.

[36] Merino-Ibarra, M., Monroy-Ríos, E., Vilaclara, G., Castillo, F.S., Gallegos, M.E. \& Ramírez-Zierold, J., Physical and chemical limnology of a wind-swept tropical highland reservoir. Aquatic Ecology, 42, pp. 335-345, 2008.

[37] Banderas, A., González-Villela, R. \& De la Lanza, G., Limnological aspects of a highmountain lake in Mexico. Hydrobiologia, 224, pp. 1-10, 1991.

[38] INEGI, Tabulados Básicos, 2013. www3.Inegi.org.mx/sistemas/tabuladosbasicos/ default.aspx? $\mathrm{c}=16763 \& \mathrm{~s}=$ est.

[39] López, O.L., Análisis de Contaminación de la Presa de Valle de Bravo, Estado de México, y sus Posibles Repercusiones en la Salud. Trabajo Final, Universidad del Medio Ambiente: Valle de Bravo, 2015. 
http://todovalle.com/pmdu/PMDU_VALLE_JULIO_12(1).pdf. Accessed on: 15 Jan. 2018.

[40] INE, La cuenca del Río Balsas. (Coordinadores). Regiones Terrestres Prioritarias de México, eds, Arriaga, L., J.M. Espinoza, C. Aguilar, E. Martínez, L. Gómez \& E. Loa, Comisión Nacional para el Conocimiento y uso de la Biodiversidad, Instituto Nacional de Ecología, 2000.

[41] PROCUENCA, Fondo PROCUENCA De Valle De Bravo, 2017. http://procuenca.org/la-cuenca-amanalco-valle-de-bravo/. Accessed on: 12 Jul. 2017.

[42] Monex Ecobanca, A.C. proyecto F013. www.ecobanca.org/proyectos/ conservacion.html. Accessed on: 5 Jun. 2017.

[43] GEM, Declaratoria del Ejecutivo del Estado por el que se establece el área natural protegida con la categoría de parque estatal denominada "Santuario del Agua valle de Bravo", en el Municipio de Valle de Bravo, Estado de México. Gaceta del Gobierno No. 96, 12 de noviembre de 2003.

[44] DOF, Decreto por el que se expropia por causa de utilidad pública una superficie de 53-45-22 hectáreas de agostadero de uso común, de terrenos del ejido Nuevo San Juan Atezcapan, Municipio de Valle de Bravo, Edo. de Méx. Diario Oficial de la Federación del 26 de abril de 2012, 2012.

[45] DOF, Decreto por el que se expropia por causa de utilidad pública una superficie de 25-85-24 hectáreas de agostadero de uso común, de terrenos del ejido Nuevo San Juan Atezcapan, Municipio de Valle de Bravo, Edo. de Méx. Diario Oficial de la Federación del Diario Oficial de la Federación del 08 de mayo de 2012, 2012.

[46] Perez, M., Castigo a la Inmobiliaria Vista del Lago: Piden al Consejo de la Judicatura Resolver controversia jurídica, exigen ejidatarios de San Juan Atezcapan. La Jornada, Octubre 22, 2004.

www.jornada.unam.mx/2004/09/22/041n1 est.php?origen=estados.php\&fly.

[47] El Financiero, Este proyecto podría acabar con hectáreas de bosque en Valle de Bravo. La Redacción, 2018. www.elfinanciero.com.mx/economia/este-proyecto-podriaacabar-con-hectareas-de-bosque-en-valle-de-bravo.html. Accessed on: 12 Jun. 2018.

[48] Trovit, https://casas.trovit.com.mx/terreno-valle-bravo-vista-lago.

[49] Enciso, A., Por salud, cierre de presa Valle de bravo: Conagua, 2012. www.jornada.unam.mx/2012/06/15/estados/036n3est.

[50] Teorema Ambiental (Environmental Theorem), Valle de Bravo, Mexico, June 29, 2012. www.teorema.com.mx/contaminacion_/altos-niveles-de-contaminacion-en-lapresa-valle-de-bravo/.

[51] Hickel, J., The contradiction of the sustainable development goals: Growth versus ecology on a finite planet. Sustainable Development, 2019.

[52] Hernández, V. \& Morillón, D., El costo de suministrar agua potable a la Zona Metropoli tana del Valle de México. Encuentro Universitario del Agua, Economía del Agua: Inversión - Financiamiento. Universidad Nacional Autónoma de México. 2006. www.agua.unam.mx/assets/pdfs/academicos/economia/hernandez_victor.pdf. Accessed on: 22 Mar. 2018.

[53] Jasser, I., Kostrzewska-Szlakowska, I., Ejsmont-Karabin, J., Kalinowska, K. \& Weglenska, T., Autotrophic versus heterotrophic production and components of trophic chain in humic lakes: The role of microbial communities. Polish Journal of Ecology, 57(3), pp. 423-439, 2008.

[54] Hager, M. et al., Beyond cockpit-ism: Four insights to enhance the transformative potential of the sustainable development goals. Sustainability, 7(2), pp. 1651-1660, 2015. 
[55] Torres, L., Sistema Lerma: Una visión política en la gestión pública del agua, ¿solución Estatal o Federal? Primera Edición: 2014 (C) Instituto de Administración Pública del Estado de México: Toluca, 2014.

[56] Cenca Janium, https://cenca.janium.net/janium-bin/pdfview.pl?Id=20190710122230 $\& \mathrm{r}=34592 \& \mathrm{t}=\mathrm{p}$.

[57] Ripple, W.J. et al., World scientists' warning to humanity: A second notice. BioScience, 67(12), pp. 1026-1028, 2017.

[58] Crutzen, P.J. \& Stoermer, E.F., The anthropocene. Global Change Newsletter, 41, pp. $17-18,2000$.

[59] Stern, N., The Economics of Climate Change: The Stern Review, Cambridge University Press: UK, 2008.

[60] Spellman, F.R., Hydraulic Facturing Wastewater: Treatment, Reuse And Disposal, CEC Press: Florida, 2017.

[61] Shutes, R.B.E., Artificial wetlands and water quality improvement. Environmental International, 26(5-6), pp. 441-447, 2001.

[62] Tharme, R.E., A global perspective on environmental flow assessment: Emerging trends in the development and application of environmental flow methodologies for rivers. River Research and Applications, 19, pp. 397-441, 2003. 